\title{
Constituent elements of the nursing consultation in the pre-natal care in the view of the pregnant women
}

\author{
Elementos constituintes da consulta de enfermagem no pré-natal na ótica de gestantes
}

Ivana Rios Rodrigues ${ }^{1}$, Dafne Paiva Rodrigues ${ }^{1}$, Márcia de Assunção Ferreira ${ }^{2}$, Maria Lúcia Duarte Pereira ${ }^{1}$, Eryjosy Marculino Guerreiro Barbosa ${ }^{1}$

Objective: to investigate the constituent elements of the nursing consultation in the prenatal care, in the view of the pregnant women. Methods: a qualitative study, undertaken based on semistructured interviews with 95 pregnant women. The samples were chosen by intentional criteria, until theoretical data saturation took place at 25 interviews, which were processed using the ALCESTE software. The participants undertook intercalated prenatal consultations between the nurse and physician. Results: the conduct undertaken in the first prenatal consultation related to arranging tests and the prescription of folic acid and ferrous sulfate, evidencing the importance of attending the consultations. Furthermore, the discourses are based on advice for general care and the filling out of the 'pregnant woman's card'2. Conclusion: based on the view of the pregnant women who participated, it was possible to identify that the nursing consultation in the prenatal period was based in technical procedures. Emphasis was placed on the providing of information, but it was not possible to identify feedback on this.

Descriptors: Pregnant Women; Prenatal care; Nursing.

Objetivo: compreender os elementos constituintes da consulta de enfermagem no pré-natal na ótica de gestantes. Métodos: estudo qualitativo, desenvolvido a partir de entrevistas semiestruturadas com 95 gestantes. Amostra escolhida por critério intencional, até ocorrência da saturação teórica dos dados, o que ocorreu com 25 entrevistas, processadas no software ALCESTE. As participantes realizavam atendimentos prénatal intercalados entre enfermeiro e médico. Resultados: a conduta realizada na primeira consulta pré-natal remete-se à solicitação de exames e prescrição das medicações ácido fólico e sulfato ferroso, evidenciando-se importância do comparecimento nas consultas. Além disso, os discursos estão baseados em orientações para cuidados gerais e acerca do preenchimento do cartão da gestante. Conclusão: a partir da ótica das gestantes participantes foi possível identificar que a consulta de enfermagem no pré-natal baseou-se em procedimentos técnicos. Houve ênfase no fornecimento de informações, porém não foi possível identificar feedback acerca destas.

Descritores: Gestantes; Cuidado Pré-Natal; Enfermagem.

\footnotetext{
${ }^{1}$ Universidade Estadual do Ceará. Fortaleza, CE, Brazil.

${ }^{2}$ Universidade Federal do Rio de Janeiro. Rio de Janeiro, RJ, Brazil. 


\section{Introduction}

The nursing consultation in the prenatal period is an important tool for the clinical nursing care for the pregnant woman, given that this is a unique moment in the woman's life ${ }^{(1)}$. The prenatal care began as individualized attendance - however, recently, it has also been addressed in groups, this approach being successful. In spite of this, one should not forget the important responsibility relating to individual attendance $^{(2)}$.

It is important to plan the care and the actions to be undertaken comprehensively with women in the gestational period, as - in this period of transformation - the women experience not only moments of happiness, but also times of fear, distress, anxiety and doubts $^{(3)}$.

The clinical care is understood as the health professional's process of care for the person seeking attendance, whether this person is healthy or has some change in their health. This attendance involves the person comprehensively, and her biological, psychological, social and spiritual dimensions. In relation to the pregnant woman, these subjective and objective dimensions of the care involve clinical and reproductive situations, which require care ${ }^{(4)}$.

Quality prenatal care is fundamental for the maternal and neonatal health, and, for its humanization and qualification, it is necessary to construct a new perspective on the health/illness process, a perspective which understands the person in her body/ mind totality and which takes into account the social, economic, cultural and physical environment in which she lives ${ }^{(1)}$.

One study undertaken in a public maternity hospital to which people are referred in the Brazilian state of Pará shows the satisfaction of women who participated in relation to the prenatal care. Their accounts showed their satisfaction with the attendance provided by the health professionals, regarding what they were advised, informed of and taught through the consultations, seminars and classes, regarding illness prevention and procedures relating to the diagnosis and treatment offered in the prenatal care, such as the undertaking of tests and the provision of vaccines ${ }^{(5)}$.

In contrast, one study undertaken in Santa Maria, Brazil, identified the quality of the prenatal care as dissatisfactory. Its assessment was related to the number of consultations, the beginning of the prenatal care, the procedures and tests undertaken, and the advice received ${ }^{(6)}$.

Represented as a singular phenomenon in a woman's life, pregnancy involves various and complex biological, psychological, social and cultural changes. Given the complexity of the event of pregnancy, the prenatal care is essential for monitoring the health of the mother-child binomial during this period. It is emphasized that the prenatal care should go beyond the biological and technicist dimension, so as to be anchored in the premises of the comprehensiveness of the care ${ }^{(7)}$.

The professionals in the prenatal consultation are seeking to meet their role as educator and promoter of health, and the services are seeking to meet the clientele's needs, through providing tests, medications and vaccines among others. In spite of this, one can also perceive that the prenatal care continues to be excessively rooted in in biomedical technology, medicalized, in the intervention, control and artificialization of the internal nature of the woman, observing that the latter does not yet have specific dominion over her body ${ }^{(5)}$.

It is important to access this universe, as, in investigating the meanings attributed and agreed regarding the nursing consultation, its contents and the network of relationships, one can understand the practices of the people who construct these and - in addition to this - understand what the weaknesses and strengths existing in this environment may be.

The study was perceived as relevant, as its results emphasized the importance of the nursing consultation in the prenatal care. The knowledge generated based on this study's results will serve as an important resource for reflecting on how the prenatal consultations undertaken by nurses in primary health care are held.

The study, therefore, aimed to investigate the 
constituent elements of the nursing consultation in the prenatal care based on the view of the pregnant women.

\section{Methods}

A qualitative study, undertaken in seven Primary Health Care Centers, belonging to the IV Regional Executive Secretary of the municipality of Fortaleza, Brazil.

A total of 95 pregnant women participated in the study. These were from different health centers and teams, and met the following inclusion criteria: they were registered in the Primary Health Care Centers studied, and were undertaking their prenatal consultations in these centers; they undertook a minimum of three prenatal consultations, so they had a minimum of experience with the research object; and they were aged between 18 and 40 years old, this age range being understood as low risk. The sample was chosen using intentional criteria, until theoretical data saturation occurred, at 25 interviews.

In the health centers studied, the pregnant women were generally attended in an intercalated way between the nurse and the physician, the first prenatal consultation always being undertaken by the professional nurse, and the second by the physician. Of the participants in the semistructured interview, seven pregnant women had already undertaken two nursing consultations and one medical consultation; nine had already undertaken three nursing consultations and two medical consultations; eight had undertaken four nursing consultations and two medical consultations; and one had undertaken five nursing consultations and three medical consultations.

Data collection, which took place between April and August 2014, was undertaken through a semistructured, individual interview, from which the researchers obtained the pregnant women's discourses on the issue, the interview being held as an informal conversation. The instrument covered the participants' sociodemographic and obstetric profile, and explored the pregnant women's analysis regarding the nursing consultation in the prenatal care.
The interviews were held after the participants accepted to participate and signed the Terms of Free and Informed Consent. The interviews took place in the centers studied, complying with the directives and regulatory norms for research involving human beings. The interviews were recorded and transcribed in full, and a database was prepared, to be processed using the ALCESTE ('Analyse Lexicale par Contexte d'un Ensemble de Segment de Texte') software - version 2012.

The ALCESTE software investigates the distribution of vocabulary in a written text and in transcriptions of oral text. As a methodology, it integrates a large number of sophisticated statistical methods, through segmentation, hierarchical classification and analysis of correspondences, this being configured as a method for exploration and description ${ }^{(8)}$.

Upon being processed in the software, initially, the pregnant women's corpus was divided $\left(1^{\text {st }}\right.$ partition) into two subcorpus, giving rise to class 1 , on the one side, and on the other to the subcorpus which later gave rise to classes 2, 3 and 4 . Class 1 is the most specific, and represents $47.0 \%$ of the corpus.

At the second point, the second subgroup was divided in two ( $2^{\text {nd }}$ repartition), obtaining class 2 (27.0\% of the corpus), and a new subgroup. Finally, this last subgroup underwent a further division $\left(3^{\text {rd }}\right.$ repartition), resulting in classes $4(18.0 \%$ of the corpus) and 3 (8.0\% of the corpus), which had more in common between them, because they were the last to be divided, The hierarchical descending classification stopped at this point, as the four classes were shown to be stable, that is, made up of elementary context units with similar vocabulary.

In the preparation of the corpus for the ALCESTE software, emphasis is placed on the attention to the materials used in its elaboration, which should have a single thematic focus, due to being the only part handled by the researcher, as a guarantee of the relevance, homogeneity and synchronism. In this perspective, the variables are defined which are termed initial context units; which served to individualize the text which is indicative of each interview ${ }^{(8)}$.

In a standard analysis, after the program has 
recognized the indications of the initial context units, the material is divided into elementary context units, that is, units with less fragmentation of meaning. The program provides, therefore, the number of classes resulting from the analysis, as well as the reduced for$\mathrm{ms}$, the semantic context, and the elementary context units which are characteristic of each class consolidated.

Once this material had been collected, the content present was clarified, naming each class based on the information provided by the software. Participants' accounts are identified by the letter P for 'pregnant' and by the number of the initial context unit generated by the software, according to the number of interviews ( 1 to 25 ).

The study respected the formal requirements contained in national and international norms regulating research involving human beings.

\section{Results}

In relation to the sociodemographic and obstetric profile of the 25 pregnant women who participated in the semistructured interview, $64.0 \%$ were multiparous, in the age range between 29 and 35 years old (60.0\%), lived with a partner (68.0\%), had completed senior high school (8.0\%) and had undertaken between three and six prenatal consultations during their current pregnancy (60.0\%).

In the analysis of the corpus of the pregnant women interviewed, 968 distinct forms or different words were found. A total of 161 elementary context units were selected, of which 131 were classified in four classes. Each class was made up of groups of various elementary context units with homogenous vocabulary. The program analyzed a volume of the text of $81.0 \%$ in this corpus.

The program produces a dendrogram, which divides the corpus into classes and which has information related to the analysis, in the form of the diagram. In this, it shows that the higher the position of a class in this diagram, the greater its specificity. The analyzable words presented in the dendrogram may be considered to be the most important elements for describing each class, as they present a greater $\mathrm{p}$.

For this study, we explored the content present in class 2, which was the second in terms of greatest statistical significance in terms of aggregation of elementary context units, making up $27.0 \%$ of the total, and which presented significant specificity. Class 1 , due to having greater specificity, has been addressed separately in another publication, and classes 3 and 4 , due to concentrating similar lexical content, have been addressed together in another publication. Class 2 , addressed in this article, was made up of 35 elementary context units and 33 analyzable words.

\section{Class 2: conducts and procedures undertaken by nurses in the prenatal consultation: pregnant women's analysis}

The illustrative words of this class, which are followed by their coefficient of association (p), are: tests $(\mathrm{p}=0.58)$, blood $(\mathrm{p}=0.52)$, results $(\mathrm{p}=0.49)$, prescribed $(\mathrm{p}=0.43)$, asked $(\mathrm{p}=0.34)$, medications $(\mathrm{p}=0.34)$, I did $(\mathrm{p}=0.31)$, to do $(\mathrm{p}=0.28)$, to take $(\mathrm{p}=0.27)$, folic acid $(p=0.27)$, ferrous sulfate $(p=0.27)$, vitamins $(p=0.26)$, I came $(\mathrm{p}=0.24)$, first $(\mathrm{p}=0.24)$, ultrasound $(\mathrm{p}=0.24)$, I saw ( $p=0.23)$, makes a note of ( $p=0.23)$. The coefficient of association is what indicates the semantic importance of each word within the class. These words express the procedures and conducts undertaken during the prenatal consultations.

The conduct undertaken in the first prenatal consultation relates mainly to the requesting of routine prenatal tests and to the beginning of taking the medications folic acid and ferrous sulfate. He arranges the blood tests which you have to do and the drugs which you have to take, which are folic acid and ferrous sulfate, and which are the vitamins which will do me and the baby good (P13). And also on the first day, she asked for the blood tests which you have to do when you're pregnant, and also that test where they put a gel on your tummy to see the size of the baby, as well as that, she prescribed for me the medications, which I'm still taking now (P2).

In addition to this, the importance of attending the prenatal consultations is evidenced. She said that I have to come to the consultations arranged, without missing any, to know if everything is okay. In the first consultation, she asked for the 
blood tests and the ultrasound, I did them and afterwards, took her the results, and she looked at them and said that everything was okay (P21). She provides guidance regarding the vaccines which I have to take and how I should take the folic acid and ferrous sulfate, which are those vitamins. She says that I have to come to all the consultations (P17).

The discourses are also based on advice for accident prevention, healthy eating and general care. She says that I mustn't travel by motorbike, because it is dangerous, and not to behave extravagantly. She says that I am to eat well, such as fruits, greens, to drink juice, and not to go near people who are ill, with flu, things like that (P24). That I shouldn't make a lot of effort, nor go up and down stairs, these measures of care that I should follow anyway. I think that there are some things in her consultation that she doesn't do, because it is already written down in my card that the doctor has already done them, it must be because of that (P4).

The interviewees also spoke about filling out the 'pregnant woman's card' (cartão da gestante). In the other consultations, she saw the results of the tests which I had done, and wrote them in the card for the doctor to see, and also for when I go to the maternity unit to have the baby, so that everything has been recorded (P22). The first time that I came for a consultation, she even asked if I had any disease, if I had ever had a miscarriage, these little basic questions, to fill out the card (P2). She spoke a lot with me, she asked various questions about my prior pregnancy, about my state of health, questions about my family, with illnesses such as depression or diabetes. She asked if I had taken the vaccine in my last pregnancy, and even asked me to bring my vaccine card so that she could see it and be certain as to whether I would need to take it or not (P22).

\section{Discussion}

In relation to this study's obstetric data, it is important to emphasize that, at a national level, of the women aged between 18 and 49 years of age, $69.2 \%$ have become pregnant at some point in their life, confirming the data from the present study, in which the majority of the women are multiparous. There are data showing the relationship between educational level/use of a method of contraception, in which $69.7 \%$ of the women with higher education completed make use of contraceptive methods and family planning, which also confirms the study's data, in which the majority of the pregnant women had not comple- ted higher education and, consequently, did not make use of contraceptive methods ${ }^{(9)}$.

The pregnant women who participated in the study had experienced more than one pregnancy, which shows significant knowledge in relation to the procedures undertaken in the nursing consultations in the prenatal care, which may have caused better feedback relating to the advice given, principally due to their being younger, having finished senior high school and having a social support network, in this case, living with partners.

The program used $81.0 \%$ of the volume of the text. When $75.0 \%$ or more of the elementary context units are classified, there is good performance of the Hierarchical Descending Classification ${ }^{(8)}$.

In relation to the illustrative words of the class addressed in this study, they expressed the procedures and conducts undertaken during the nursing consultations in the prenatal care, and what one can observe, from the words with a greater association with this class and from the elementary context units, is that these procedures are geared firstly towards the routine tests to be undertaken in the prenatal care, the essential medications for the progression of a healthy pregnancy, and the records undertaken during the act of the consultation.

In the study's results, it was possible to observe compliance with the stipulations made in the Notebook on Care in the Pre-natal Period for the Low Risk Pregnancy (Caderno de Atenção ao Pré-natal de Baixo Risco), proposed by the Brazilian Ministry of Health, as the nurse's actions in this type of care are: to advise the women and their family members regarding the importance of the prenatal care, of breast-feeding and vaccination; to request the complementary tests, according to the local prenatal protocol; to undertake fast tests; to prescribe standardized medications for the prenatal program; to advise the pregnant women's vaccination; to undertake educational activities, both individual and in groups; to advise the pregnant women about the regularity of the consultations, and to undertake active searching for the pregnant women who do not attend their consultations, as well as other actions ${ }^{(1)}$. 
Emphasis is also placed on other topics in the literature relating to the content of the advice received from the professionals who undertook the prenatal consultations, these being discussions on diet, physical activity, stress, medication, sexual activity and control of weight ${ }^{(10)}$.

This corroborates a study undertaken in João Pessoa, Brazil, whose services as a whole undertook the clinical-obstetric procedures considered the minimum necessary for the prenatal care, such as activities additional to the consultations, of health education; monitoring the quality of the prenatal care; advice regarding diet, breast-feeding and vaccination; and the prescribing of supplements ${ }^{(11)}$.

The high percentage of supplement use becomes important, as this aims to control the shortage of micronutrients which are essential for the health of the mother and fetus ${ }^{(12)}$.

The prenatal care consists of the physical examination of the pregnancy, investigation of the gynecological-obstetric antecedents, the history of comorbidities and socioeconomic data, in conjunction with the advice passed on, which makes up the health education work which helps women to clarify doubts and discourage inappropriate conducts, for them to feel safer and more confident, and to be better-prepared during the pregnancy ${ }^{(13)}$.

The interviewees also spoke about filling out the pregnant woman's card, reporting that the nurses delineate the obstetric profile and the history of personal and family antecedents - which mainly happens in the first prenatal consultation - and make records regarding tests, vital signs and gestational age, among others, in the subsequent consultations. This is an instrument for the assessment and progression of the pregnancy, which reinforces the great responsibility of the professional, which involves the filling out of the records in the pregnant woman's card. It is emphasized that recording the results obtained in a banal, careless and automatized way is not enough. It is necessary for there to be critical analysis of this data and its interrelationship with the clinical status, so that there may be appropriate interpretation ${ }^{(14)}$.

In addition to this, through the pregnant women's accounts, it was evidenced that the nurses heavily emphasized that the pregnant women should not miss their prenatal consultations arranged and that they were to take the necessary vaccines during the gestational period.

For better adaptation of the prenatal actions in the ambit of the care, it is possible to affirm that the advice must be directed towards extending the prenatal coverage in the first trimester, with a minimum of six consultations, basic tests and the anti-tetanus vaccine; besides encouraging health education activities and indicators which monitor internally the quality of the prenatal care ${ }^{(11)}$.

Quality prenatal care is produced through everybody's involvement in the process - whether these are professionals, service users or family members - making use of all the means existent in the community and in the environment, for facilitating the actions and improvement of the service users' satisfaction, through efficacious, comprehensive and equal care $^{(15)}$.

During the interviews, it was not possible, through the pregnant women's accounts, to identify the feedback in relation to the advice given by the professionals during the prenatal consultations. This advice, as can be perceived in the accounts, was prescriptive, in which the professional brought a feeling of compulsoriness for the pregnant woman to follow the advice, which was general, that is to say, was not aimed specifically at the needs of each one. Besides this non-perception of feedback, at no point did the pregnant women talk about the possibility of following the advice or not; they simply mentioned that they received it.

This evokes the need for the ongoing empowerment of the professional nurses, in the sense of increasing actions of health promotion and prevention of ill health which take into account this clientele's specific characteristics and needs, with information and training in health - thus allowing not only prescriptive advice, but a better way of allowing feedback in relation to the advice received ${ }^{(16)}$.

In the study, the pregnant women mentioned having received various pieces of important advice, 
among which they emphasized care during the pregnancy, with essential nutrition in this period, and that they should have autonomy and responsibility in relation to the pregnancy.

In the reproductive period, the distress regarding the unknown and the fear about the result of the pregnancy generate conflicts for the pregnant woman. This is a propitious time for establishing good links, as the woman is more receptive. Therefore, the intersection of the committed professional, who is involved with the woman's psychosocial needs, can clarify the process of pregnancy and giving birth - and, as a result, restore the feminine power of autonomy and decision over her body ${ }^{(16)}$.

However, considering the reality of life in society, the exercising of autonomy depends on cultural, social, economic and other conditions. People are motivated by their own will, but also by the will of the world around them, which confers a relative and relational characteristic to the autonomy, which is inseparable from the dependency ${ }^{(17)}$.

In the interviews, the following were shown: technicism, technical procedures undertaken, the prescription of advice, and filling out of instruments necessary for conducting the prenatal consultations, which demonstrates the mechanical character of the attendance.

Witnessing to this, one study depicts that there are divergent ways of thinking about the phenomenon of pregnancy, but that in practice, everybody operationalizes their actions with a technicist basis, in such a way that compliance with institutional routines and protocols is superimposed upon the woman's uniqueness. Therefore, the prenatal care is distanced from the perspective of comprehensiveness, to the extent that the professionals - although inserted in programs which value the relationships of care - are kept tied to the bases of their training, guided by ideological subjections to a model which denies the pregnant women the opportunity to be individuals ${ }^{(18)}$.

Besides this, it is also important to highlight that in the prenatal care, the nurse has a technical and scientific basis for addressing the woman and, due to having a holistic vision, creates links with the woman, seeing the pregnancy not simply as a natural process of procreation, but visualizing the woman and mother as a person who has needs. This ability to create a bond makes the nursing consultation different, as it is not centered only on technical procedures - but that dialogue exists as a fundamental part ${ }^{(19)}$.

In the study, it was not possible to focus on the comprehensiveness in the attendance, and a bond between the pregnant woman and professional - only, as mentioned, technical consultations, in which there is verticalization of the advice and information provided.

As limitations, there is the large number of multiparous pregnant women who participated in the study, whose accounts may have been associated with experiences of previous pregnancies and prenatal care. Furthermore, the small number of primiparous pregnant women did not allow the researchers to effectively elucidate the constituent elements of the nursing consultation for this group of pregnant women.

\section{Conclusion}

Based on the viewpoint of the pregnant women studied, it was possible to identify that the nursing consultation in the prenatal care was partly based in technical procedures; but that dialogue was also present with the professional regarding the pregnancy, the advice and the counseling, which form part of the professionals' attendance, as a means of leading the women to have a better pregnancy.

In the nursing consultation, from the pregnant women's reports, it was possible to observe emphasis on encouragement for self-care, contributing to autonomy and responsibility, in partnership with the health professional, besides the provision of information regarding diet, general care during the pregnancy and the prevention of complications, and the management of the clinical care for the pregnant woman. It was not possible, however, to identify feedback regarding the advice given, nor on the possibility of following the advice. Furthermore, it was not possible to focus on whether the pregnant women's needs were considered during the nursing consultation. 


\section{Collaborations}

Rodrigues IR and Rodrigues DP contributed to the conception, analysis, data interpretation, editing of the article and final approval of the version to be published. Ferreira MA, Pereira MLD and Barbosa EMG contributed to the editing of the article, relevant critical revision of the intellectual content, and final approval of the version to be published.

\section{References}

1. Ministério da Saúde (BR). Cadernos de Atenção Básica: Atenção ao pré-natal de baixo risco. Brasília: Ministério da Saúde; 2012.

2. Gennaro S, Melnyk BM, O'Connor C, Gibeau AM, Nadel E. Improving prenatal care for minority women. Am J Matern Child Nurs. 2016; 41(3):14753.

3. Arrais AR, Araújo TCCF. Pré-natal psicológico: perspectivas para ação do psicólogo em saúde materna no Brasil. Rev SPBH. 2016; 19(1):103-16.

4. Silveira LC, Vieira NA, Monteiro ARM, Miranda KCL, Silva LF. Cuidado clínico em enfermagem: desenvolvimento de um conceito na perspectiva de reconstrução da prática profissional. Esc Anna Nery. 2013; 17(3):548-54.

5. Castro ME, Moura MAV, Silva LMS. Qualidade da assistência pré-natal: uma perspectiva das puérperas egressas. Rev Rene. 2010; 11 (n. esp):72-81.

6. Anversa ETR, Bastos GAN, Nunes LN, Pizzol TSD. Qualidade do processo da assistência pré-natal: unidades básicas de saúde e unidades de Estratégia Saúde da Família em município no Sul do Brasil. Cad Saúde Pública. 2012; 28(4):789-800.

7. Shimizu HE, Lima MG. As dimensões do cuidado pré-natal na consulta de enfermagem. Rev Bras Enferm. 2009; 62(3):387-92.

8. Azevedo DM, Costa RKS, Miranda FAN. Uso do ALCESTE na análise de dados qualitativos: contribuições na pesquisa em enfermagem. Rev Enferm UFPE on line [Internet]. 2013 [citado 2016 fev 15]; 7(esp):5015-22. Disponível em: http:// www.revista.ufpe.br/revistaenfermagem/index. php/revista/article/view/3297
9. Ministério da Saúde (BR). Secretaria de Vigilância em Saúde. Saúde Brasil 2011: uma análise da situação de saúde e a vigilância da saúde da mulher. Brasília: Ministério da Saúde; 2012.

10. Etges MR, Oliveira DLLC, Cordova FP. A atenção pré-natal na ótica de um grupo de mulheres usuárias do subsetor suplementar. Rev Gaúcha Enferm. 2011; 32(1):15-22.

11. Silva EP, Lima RT, Ferreira NLS, Costa MJC. Pré-natal na atenção primária do município de João Pessoa-PB: caracterização de serviços e usuárias. Rev Bras Saúde Matern Infant. 2013; 13(1):29-37.

12. Long KZ, Garcia C, Ko G, Santos JI, Al Mamun A, Rosado JL, et al. Vitamin A modifies the intestinal chemokine and cytokine responses to norovirus infection in Mexican children. J Nutr. 2011; 141(5):957-63.

13. Silva JWS. A importância das orientações no pré-natal: o que deve ser trabalhado pelos profissionais e a realidade encontrada. Enciclop Biosfera. 2010; 6(9):1-29.

14. Gonçalves LA, Costa LC, Ferreira VL, Abreu MS. Avaliação dos registros do número de consultas de pré-natal no cartão da gestante, sanitas e sisprenatal. RAHIS. 2014; 11(4):266-77.

15. Guerreiro EM, Rodrigues DP, Silveira MAM, Lucena NBF. 0 cuidado pré-natal na atenção básica de saúde sob o olhar de gestantes e enfermeiros. Rev Min Enferm. 2012; 16(3):315-23.

16. Souza VB, Roecker S, Marcon SS. Ações educativas durante a assistência pré-natal: percepção de gestantes atendidas na rede básica de Maringá-PR. Rev Eletr Enf [Internet]. 2011 [citado 2016 abr 22]; 13(2):199-210. Disponível em: http://dx.doi. org/10.5216/ree.v13i2.10162.

17. Weidle WG, Medeiros CRG, Grave MTQ Bosco, SMD. Escolha da via de parto pela mulher: autonomia ou indução? Cad Saúde Coletiva. 2014; 22(1):46-53.

18. Melo MCP, Coelho EAC. Integralidade e cuidado a grávidas adolescentes na Atenção Básica. Ciênc Saúde Coletiva. 2011; 16(5):2549-58.

19. Araújo SM, Silva MED, Moraes RC, Alves DS. A importância do pré-natal e a assistência de enfermagem. Veredas FAVIP. Rev Eletr Ciênc [Internet]. 2010 [citado 2016 abr 22]; 3(2):61-7. Disponível em: http://www.veredas.favip.edu.br/ojs/index. $\mathrm{php} /$ veredas1/article/view/98 